\title{
Chemotaxonomic Study of an Alkalophilic Bacterium, Exiguobacterium aurantiacum gen. nov., sp. nov.
}

\author{
By M. D. COLlinS, ${ }^{1 *}$ B. M. LUND, ${ }^{2}$ J. A. E. FARROW ${ }^{1}$ AND \\ K. H. SCHLEIFER ${ }^{3}$ \\ ${ }^{1}$ Department of Microbiology, National Institute for Research in Dairying, Shinfield, \\ Reading RG2 9AT, U.K. \\ ${ }^{2}$ Department of Microbiology, Food Research Institute, Colney Lane, Norwich NR4 7UA, U.K. \\ ${ }^{3}$ Lehrstuhl Mikrobiologie, Institut Botanik und Mikrobiologie, Technische Universität München, \\ 8 München 2, Arcisstrasse 21, Federal Republic of Germany
}

(Received 10 December 1982; revised 28 January 1983)

Chemical studies were performed on a Gram-positive alkalophilic bacterium of uncertain taxonomic position. On the basis of the present and earlier studies it is suggested that the alkalophilic bacterium be classified in a new genus Exiguobacterium, as Exiguobacterium aurantiacum gen. nov., sp. nov.

\section{INTRODUCTION}

The isolation of five strains of an alkalophilic bacterium from potato-processing effluent was reported by Gee et al. (1980). The bacterium was Gram-positive, non-sporing, facultatively anaerobic and varied in shape from rods to almost coccoid forms. In some respects it resembled certain coryneform bacteria but its true taxonomic position was not determined (Gee et al., 1980).

Recent improvements in the classification of coryneform and related bacteria have been made possible by analyses of cell wall peptidoglycan (Schleifer \& Kandler, 1972), DNA base composition (Crombach, 1978) and lipid composition (Minnikin et al., 1978; Collins \& Jones, 1981). In the present study these techniques have been used to characterize further the alkalophilic bacterium of Gee et al. (1980) in an attempt to clarify its classification.

\section{METHODS}

Cultures and cultivation. For cell wall and lipid studies, five strains, BL77/1 to BL77/5, were cultivated in shake flasks of nutrient broth no. 2 (Oxoid) $\mathrm{pH} 7.8$ at $30^{\circ} \mathrm{C}$ for $3 \mathrm{~d}$. Cultures were checked for purity, harvested by centrifugation $(10000 \mathrm{~g})$, washed with distilled water and freeze-dried.

Peptidoglycan analysis. The peptidoglycan type of two strains (BL77/1 and BL77/2) was determined as described by Schleifer \& Kandler (1972). Purified walls were prepared from about $500 \mathrm{mg}$ of dry cells, and the qualitative amino acid composition of the partial and complete wall hydrolysates was determined by paper chromatography. Quantitative determinations were made using an automatic amino acid analyser.

DNA base composition determinations. Strains BL77/1 and BL77/2 were grown to late-exponential phase, harvested by centrifugation and washed twice in distilled water. DNA was extracted and purified as described by Garvie et al. (1981). The DNA base composition was determined from its melting temperature in standard saline citrate as described by Garvie et al. (1981).

Analysis of polar lipids. Free lipids were extracted from dry organisms (50 mg) as described previously (Minnikin et al., 1979). Polar lipids were examined by two-dimensional thin-layer chromatography using HPTLC Kieselgel $60 \mathrm{~F}_{254}$ (Merck Art. 5628) plates $(10 \times 10 \mathrm{~cm}$ ). Chromatograms were developed in the first dimension with chloroform/methanol/water $(65: 25: 4$, by vol. $)$ and in the second dimension with chloroform $/ \mathrm{methanol} /$ acetic acid/water $(80: 12: 15: 4$, by vol.). Spraying with $10 \%(\mathrm{w} / \mathrm{v})$ molybdophosphoric acid in ethanol followed by heating at $150{ }^{\circ} \mathrm{C}$ for $15 \mathrm{~min}$ revealed all the lipids present. Specific spray reagents for lipid phosphate (Dittmer \& 
Lester, 1964), $\alpha$-glycols (Shaw, 1968), sugars ( $\alpha$-naphthol and anisaldehyde $/ \mathrm{H}_{2} \mathrm{SO}_{4}$ ) (Jacin \& Mishkin, 1965; Stahl $\&$ Kaltenbach, 1961) and free amino groups (ninhydrin) were also used.

Analysis of isoprenoid quinones. Isoprenoid quinones were extracted from dry cells $(50 \mathrm{mg})$ and purified as described by Collins et al. (1977). Purified quinones were further examined by reverse-phase partition chromatography as described previously (Collins et al. 1980b, 1982a). Mass spectra of the quinones were recorded on an AEI MS9 instrument using a direct insertion probe, an ionizing voltage of $70 \mathrm{eV}$ and a temperature range of 180 to $200{ }^{\circ} \mathrm{C}$

\section{RESULTS AND DISCUSSION}

The purified peptidoglycan of strains BL77/1 and BL77/2 contained lysine as the dibasic amino acid. In addition alanine, glycine and glutamic acid were detected in the hydrolysates. Analysis of partial hydrolysates indicated the presence of a group A peptidoglycan (type Lysineglycine $_{1}$ ) (Schleifer \& Kandler, 1972). This peptidoglycan type has been reported previously in certain coryneform taxa (e.g. Brevibacterium acetylicum) and bifidobacteria (Schleifer \& Kandler, 1972; Weiss et al., 1981). The peptidoglycan of strains BL77/1 and BL77/2 also resembles that of staphylococci, except that the latter normally have several glycine residues (i.e. Lysine-glycine $_{4-5}$; Schleifer \& Kandler, 1972).

The DNA base composition of strains BL77/1 and BL77/2 was 53.4 and $53.2 \mathrm{~mol} \% \mathrm{G}+\mathrm{C}$ respectively. The present result is lower than that reported $(56 \mathrm{~mol} \% \mathrm{G}+\mathrm{C})$ for strain BL77/1 by Gee et al. (1980). A mol \% G + C range of 53 to 54 is compatible with certain coryneform bacteria (see Table 1) but significantly higher than that reported for members of the genus Staphylococcus (Schleifer et al., 1979a,b). The mol \% G $+\mathrm{C}$ range of 53 to 54 is also higher than that of most members of the genus Bacillus, although some Bacillus spp. possess DNA base ratios of 50 to $62 \mathrm{~mol} \% \mathrm{G}+\mathrm{C}$ (Gibson \& Gordon, 1974).

Components that co-chromatographed with vitamin $\mathrm{K}$ were the only isoprenoid quinones detected in the test strains (BL77/1 to BL77/5). UV absorption spectra of the purified quinones showed absorption maxima at 242,248,260,269 and $325 \mathrm{~nm}$, in accord with published data for menaquinones (Collins \& Jones, 1981). The mass spectra of the menaquinone samples showed intense peaks at $m / e 187$ and 225 derived from the naphthoquinone nucleus with peaks in the high mass region ( $m / e$ 648, 580, 512; major component in bold) attributable to molecular ions $\left(\mathrm{M}^{+}\right)$. The major component corresponded to unsaturated menaquinones with seven isoprene units (abbreviated MK-7) although trace amounts of MK-6 and MK-5 were also present. The recovery of major amounts of MK-7 from the alkalophilic strains differentiates them from members of the 'coryneform group of bacteria' (Collins \& Jones, 1981). Major amounts of MK-7 have however been reported to be present in a variety of other Gram-positive taxa (e.g. Bacillus, Kurthia, Staphylococcus) (Collins \& Jones, 1981).

Diphosphatidylglycerol (DPG), phosphatidylglycerol (PG) and phosphatidylethanolamine (PE) were readily identified in the extracts of the test strains by their chromatographic behaviour and staining characteristics. In addition the test strains possessed minor amounts of an unidentified phospholipid (Fig. 1). No glycolipids were detected. The presence of PE in the test strains is of considerable interest. With the exception of a few mycolic acid-containing taxa (Minnikin et al., 1978) PE is not normally found in coryneform bacteria. Although PE is common amongst Bacillus species, the latter also possess glycolipids (Shaw, 1970; Lechevalier, 1977). It is worth noting that Kurthia zopfii also possesses the simple polar lipid pattern DPG, PG and PE (Goodfellow et al., 1980).

The results of the present study indicate that the alkalophilic bacterium of Gee et al. (1980) is quite distinct from all Gram-positive eubacteria examined to date (Table 1). The alkalophilic bacterium can be distinguished from all members of the 'coryneform group of bacteria' on the basis of cell wall peptidoglycan, mol $\% \mathrm{G}+\mathrm{C}$, polar lipid and menaquinone composition. Although the alkalophilic bacterium resembles Kurthia zopfii in possessing a peptidoglycan based upon lysine, unsaturated menaquinones with seven isoprene units and a polar lipid composition comprising DPG, PG and PE, the former has a relatively low $\mathrm{G}+\mathrm{C}$ content (about $37 \mathrm{~mol} \%$; Keddie, 1981). The alkalophilic bacterium can also be distinguished from the vast majority of Bacillus spp. on the basis of its cell wall composition. Members of the genus 


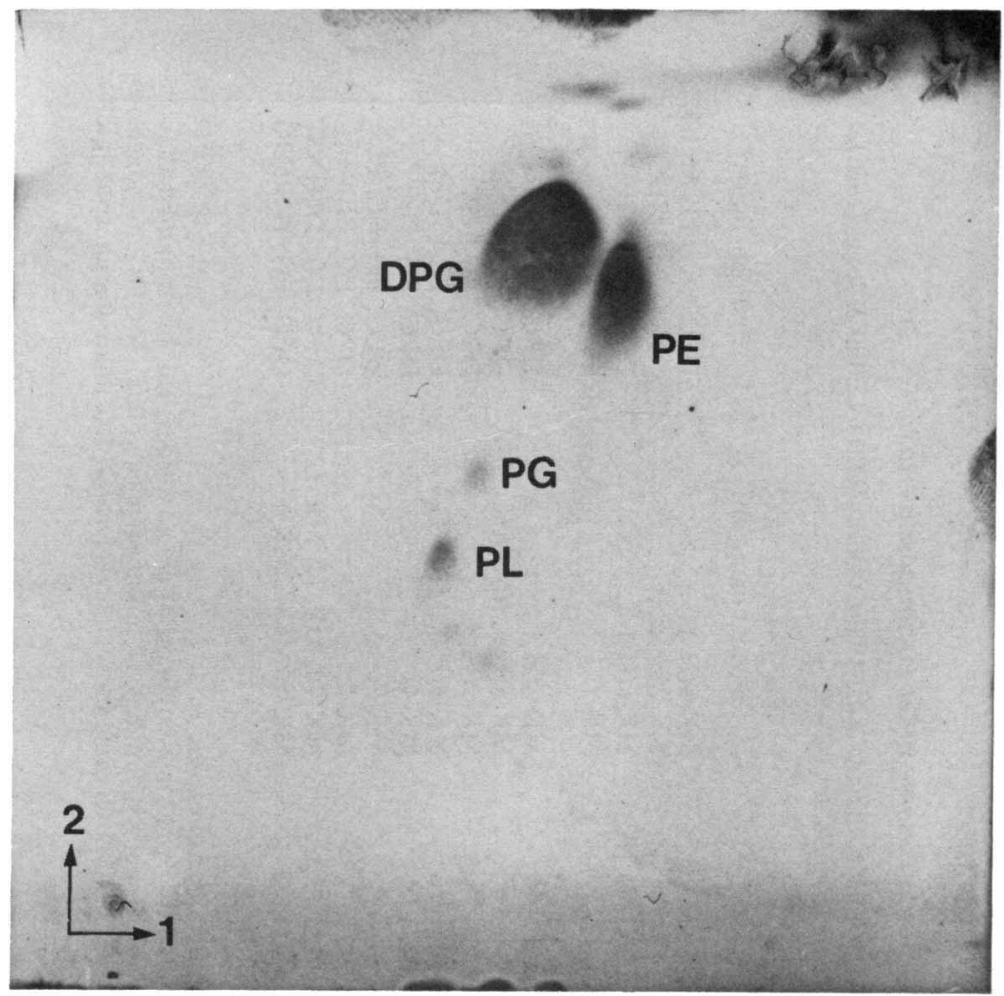

Fig. 1. Two-dimensional thin-layer chromatogram of polar lipids from strain BL77/1. Chloroform/ methanol/water $(65: 25: 4$, by vol.) was used in the first dimension and chloroform $/ \mathrm{methanol} / \mathrm{acetic}$ acid/water $(80: 12: 15: 4$, by vol.) in the second dimension. Abbreviations: DPG, diphosphatidyl glycerol; PG, phosphatidylglycerol; PE, phosphatidylethanolamine; PL, unknown phospholipid.

Bacillus generally possess a directly cross-linked peptidoglycan based on meso-diaminopimelic acid (Schleifer \& Kandler, 1972). Two alkalophilic bacilli, B. pasteurii and B. sphaericus, have however been reported to possess peptidoglycans based on lysine (Schleifer \& Kandler, 1972). The DNA base compositions of B. pasteurii $(42 \mathrm{~mol} \% \mathrm{G}+\mathrm{C}$ ) and B. sphaericus ( 37 to $43 \mathrm{~mol} \%$ $\mathrm{G}+\mathrm{C}$ ) (Gibson \& Gordon, 1974) are however incompatible with that of the alkalophilic bacterium (about $53 \mathrm{~mol} \% \mathrm{G}+\mathrm{C}$ ). Thus on the basis of phenetic (Gee et al., 1980), cell wall peptidoglycan, mol \% G $+\mathrm{C}$ and lipid data, the alkalophilic bacterium appears to be quite distinct from all other Gram-positive taxa examined to date. We therefore propose that the alkalophilic bacterium of Gee et al. (1980) be classified in a new genus, Exiguobacterium (L. adj. exiguus short, small; Gr. neut. dim. n. bakterion a small rod; M.L. neut. n. Exiguobacterium small rod), as Exiguobacterium aurantiacum sp. nov.

\section{Description of Exiguobacterium gen. nov.}

Cells vary in shape from rods $(3.2 \times 1.2 \mu \mathrm{m})$ in the exponential phase to short, almost coccoid forms $(1.4 \times 1.1 \mu \mathrm{m})$ in the stationary phase (Gee et al., 1980). Both rods and coccoid cells are Gram-positive, non-acid fast and motile; endospores are not formed. The organism is facultatively anaerobic, catalase positive and oxidase negative. Acid is produced from glucose, sucrose, galactose and some other sugars. In anaerobic conditions with glucose as substrate, lactate, acetate and formate are major end products, the proportions depending on cultural conditions (Gee et al., 1980). The cell wall contains a group A type peptidoglycan based on lysine. Mycolic acids are not present. Menaquinones are the sole respiratory quinones; the principal quinone is MK-7. The major polar lipids consist of diphosphatidylglycerol, phosphatidylglycerol and phosphatidylethanolamine. The DNA base compositions of two strains are 53.2 to $55.8 \mathrm{~mol} \% \mathrm{G}+\mathrm{C}$. The type species is Exiguobacterium aurantiacum. 


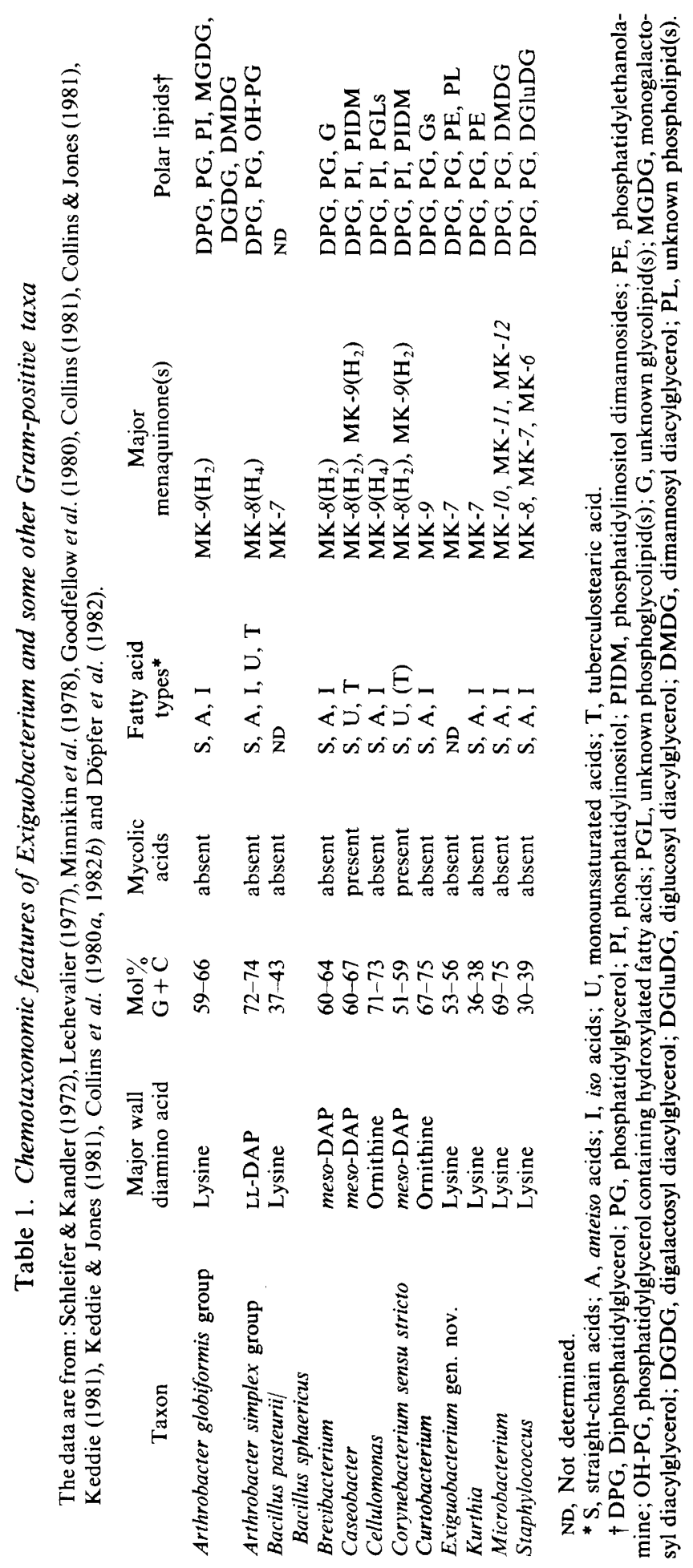


Description of Exiguobacterium aurantiacum sp. nov.

Exiguobacterium aurantiacum (au.ran.ti'ac.um. L. neut. n. aurum gold; M.L. neut. n. Aurantium generic name of the orange; M.L. neut. adj. aurantiacum orange-coloured).

Surface colonies on PPYG agar (Gee et al., 1980) are 2 to $3 \mathrm{~mm}$ in diameter after $3 \mathrm{~d}$ at $25^{\circ} \mathrm{C}$, low convex, orange, opaque, butyrous and easily emulsified. Colonies on heart infusion agar are normally flat and fainter orange. Orange pigment does not diffuse into medium; pigment production does not occur anaerobically. Cells vary in shape from short, almost coccoid forms $1.4 \times 1.1 \mu \mathrm{m}$ in the stationary phase to rods $3.2 \times 1.2 \mu \mathrm{m}$ in the exponential phase (Gee et al., 1980). Longer, distorted rods may be formed during exponential growth at $\mathrm{pH}>10$. Cells are Gram-positive, non-acid fast, non-sporing. Motile (peritrichous flagella). Growth occurs in aerobic and anaerobic conditions. Optimum temperature for growth (at $\mathrm{pH} 9.5$ ) about $37^{\circ} \mathrm{C}$; temperature range of growth is from 7 to $43{ }^{\circ} \mathrm{C}$; at $25^{\circ} \mathrm{C}$ the $\mathrm{pH}$ range for growth is about 6.5 to 11.5 , with two maxima, at $\mathrm{pH} 8.5$ and $\mathrm{pH} 9.5$ (Gee et al. 1980). Catalase positive, oxidase negative, glucose metabolized fermentatively. Acid produced from glucose, galactose, glycerol, maltose, mannitol and sucrose but not from L-arabinose, dulcitol, lactose, melezitose, raffinose, rhamnose, sorbitol or xylose. Acid sometimes produced from fructose and salicin. In anaerobic conditions with glucose as substrate, lactate, acetate and formate are the major end products, the proportions depending on cultural conditions. Starch, casein and gelatin are hydrolysed but carboxymethylcellulose, dextran, pectin, tributyrin and Tween 80 are not attacked. Nitrate is reduced to nitrite. Growth is inhibited by chloramphenicol $(10 \mu \mathrm{g}$ per disc), erythromycin $(10 \mu \mathrm{g})$, novobiocin $(5 \mu \mathrm{g})$, oleandomycin $(5 \mu \mathrm{g})$, penicillin $\mathrm{G}(1.0 \mu \mathrm{g})$ and tetracycline $(10 \mu \mathrm{g})$ but not sulphafurazole $(100 \mu \mathrm{g})$.

The cell wall peptidoglycan is based on lysine (type Lysine-glycine ${ }_{1}$ ). Mycolic acids are not present. The principal isoprenoid quinone is MK-7. The major polar lipids consist of diphosphatidylglycerol, phosphatidylglycerol and phosphatidylethanolamine. The $\mathrm{G}+\mathrm{C}$ content of the DNA, determined by estimation of the melting point, is 53.2 to $55.8 \mathrm{~mol} \%$ (Gee et al., 1980; present work). The type strain is NCIB 11798.

\section{REFERENCES}

Collins, M. D. (1981). Distribution of menaquinones within members of the genus Staphylococcus. FEMS Microbiology Letters 12, 83-85.

Collins, M. D. \& Jones, D. (1981). The distribution of isoprenoid quinone structural types in bacteria and their taxonomic implications. Microbiological Reviews 45, 316-354.

Collins, M. D., Pirouz, T., Goodfellow, M. \& Minnikin, D. E. (1977). Distribution of menaquinones in actinomycetes and corynebacteria. Journal of General Microbiology 100, 221-230.

Collins, M. D., Goodfellow, M. \& Minnikin, D. E. $(1980 a)$. Fatty acid, isoprenoid quinone and polar lipid composition in the classification of Curtobacterium and related taxa. Journal of General Microbiology 118, 29-37.

Collins, M. D., Shah, H. N. \& Minnikin, D. E. $(1980 b)$. A note on the separation of natural mixtures of bacterial menaquinones using reverse-phase thinlayer chromatography. Journal of Applied Bacteriology 48, 277-282.

Collins, M. D., McCarthy, A. J. \& Cross, T. (1982a). New highly saturated members of the vitamin $\mathrm{K}_{2}$ series from Thermomonospora. Zentralblatt für Bakteriologie und Hygiene (I. Abteilung, Originale C) 3, 358-363.

Collins, M. D., Goodfellow, M. \& Minnikin, D. E. $(1982 b)$. Fatty acid composition of some mycolic acid-containing coryneform bacteria. Journal of General Microbiology 128, 2503-2509.
Crombach, W. H. J. (1978). DNA base ratios and DNA hybridization studies of coryneform bacteria, mycobacteria and nocardiae. In Coryneform Bacteria, pp. 161-179. Edited by I. J. Bousfield \& A. C. Callely. London: Academic Press.

Dittmer, J. C. F. \& Lester, R. L. (1964). A simple specific spray for the detection of phospholipids on thin-layer chromatograms. Journal of Lipid Research 5, 126-127.

Döpfer, H., Stackebrandt, E. \& Fiedler, F. (1982). Nucleic acid hybridization studies on Microbacterium, Curtobacterium, Agromyces and related taxa. Journal of General Microbiology 128, 16971708.

Garvie, E. I., Farrow, J. A. E. \& Phillips, B. A. (1981). A taxonomic study of some strains of streptococci which grow at $10^{\circ} \mathrm{C}$ but not at $45^{\circ} \mathrm{C}$ including Streptococcus lactis and Streptococcus cremoris. Zentralblatt für Bakteriologie und Hygiene (I. Abteilung, Originale C) 2, 151-165.

Gee, J. M., Lund, B. M., Metcalf, G. \& Peel, J. L. (1980). Properties of a new group of alkalophilic bacteria. Journal of General Microbiology 117, 9-17.

Gibson, T. \& Gordon, R. E. (1974). Genus Bacillus. In Bergey's Manual of Determinative Bacteriology, pp. 529-550. Edited by R. E. Buchanan \& N. E. Gibbons. Baltimore: Williams \& Wilkins.

Goodfellow, M., Collins, M. D. \& Minnikin, D. E. (1980). Fatty acid and polar lipid composition of Kurthia. Journal of Applied Bacteriology 48, 269-276. 
JACIN, H. \& MishKIN, A. R. (1965). Separation of carbohydrates on borate-impregnated silica gel $\mathrm{G}$ plates. Journal of Chromatography 18, 170-173.

Keddie, R. M. (1981). The genus Kurthia. In The Prokaryotes: A Handbook on Habitats, Isolation and Identification of Bacteria, pp. 1888-1893. Edited by M. P. Starr, H. Stolp, H. G. Trüper, A. Balows \& H. G. Schlegel. Heidelberg: Springer-Verlag.

KedDie, R. M. \& Jones, D. (1981). Saprophytic, aerobic coryneform bacteria. In The Prokaryotes: $A$ Handbook on Habitats, Isolation and Identification of Bacteria, pp. 1838-1878. Edited by M. P. Starr, H. Stolp, H. G. Trüper, A. Balows \& H. G. Schlegel. Heidelberg: Springer-Verlag.

LechevalieR, M. P. (1977). Lipids in bacterial taxonomy - a taxonomist's view. CRC Critical Reviews in Microbiology 5, 109-210.

Minnikin, D. E., Goodfellow, M. \& Collins, M. D. (1978). Lipid composition in the classification and identification of coryneform and related taxa. In Coryneform Bacteria, pp. 85-160. Edited by I. J. Bousfield \& A. C. Callely. London: Academic Press. Minnikin, D. E., Collins, M. D. \& Goodfellow, M. (1979). Fatty acid and polar lipid composition in the classification of Cellulomonas, Oerskovia and related taxa. Journal of Applied Bacteriology 47, 87-95.
Schleifer, K. H. \& KandleR, O. (1972). Peptidoglycan types of bacterial cell walls and their taxonomic implications. Bacteriological Reviews 36, 407-477.

Schleifer, K. H., Meyer, S. A. \& Rupprecht, M. $(1979 a)$. Relatedness among coagulase-negative staphylococci: deoxyribonucleic acid reassociation and comparative immunological studies. Archives of Microbiology 122, 93-101.

SChleifer, K. H., Meyer, S. A. \& Heise, W. (1979b). Deoxyribonucleic acid hybridization studies among some micrococci. FEMS Microbiology Letters 6, 3336.

SHAw, N. (1968). The detection of lipids on thin-layer chromatograms with the periodate-Schiff reagent. Biochimica et biophysica acta 164, 435-436.

SHAw, N. (1970). Bacterial glycolipids. Bacteriological Reviews 34, 365-377.

Stahl, E. \& Kaltenbach, U. (1961). Dünnschicht Chromatographie. VI. Mitteilung. Spurenanalyse von Zuckergemischen auf Kieselgur G-Schichten. Journal of Chromatography 5, 351-355.

Weiss, N., SCHLEIFER, K. H. \& Kandler, O. (1981). The peptidoglycan types of Gram-positive anaerobic bacteria and their taxonomic implications. Revue de l'Institut Pasteur de Lyon 14, 3-12. 